\title{
The evaluation of flora and fauna in coal mine reclamation land (case study: PT Dharma Puspita Mining, East Kalimantan, Indonesia)
}

\author{
T Yunanto Ministry of Energy and Mineral Resources, Indonesia \\ F Amanah Ministry of Energy and Mineral Resources, Indonesia \\ TH Gultom EHS Department, Harita Group, Indonesia
}

S Asdini EHS Department, Harita Group, Indonesia

\begin{abstract}
It is inevitable that mining exploitation, in addition to having a positive impact on national income can also have a negative impact on the environment, such as reduced diversity of both flora and fauna. To restore environmental functions, mining companies are required to carry out mine reclamation. Environmental management that needs to be carried out after reclamation activities are monitoring and evaluating the success of reclamation, especially flora and fauna diversity, such as vegetation, avifauna and mammals. The purposes of this study were: 1) to identify and measure the biodiversity of terrestrial flora, 2) to identify and measure the biodiversity of avifauna and mammal species, 3) to determine the conservation status of flora and fauna in the reclamation area, and 4) to compare the biodiversity of flora and fauna in the reclamation area and secondary natural forest. The studies were carried out in 3 reclamation areas (year of plantation: 2006, 2007 and 2008), and secondary forests nearby as comparison. Line plot sampling was used in the vegetation studies. Both direct observation and catching up with mist net were taken in the avifauna and mammal evaluation. In addition, footprint identification was used in mammal investigation. The results showed that the Shannon-Wiener index $\left(H^{\prime}\right)$ of reclamation 2007 and $2008\left(H^{\prime}=3.04\right)$ for sapling stage was higher than secondary forests $\left(H^{\prime}=2.56\right)$. Generally, vegetation in the reclamation area was dominated by the family of Euphorbiaceae (9 species), Rubiaceae (6 species), and Leguminosae (5 species). Among of them, 8 species were included in the International Union for Conservation of Nature (IUCN) red list and 1 species was included in Convention on International Trade in Endangered Species of Wild Fauna and Flora (CITES) Appendices II. Species of birds found in the reclamation area were about 59 species which were dominated by open area bird species and shrubs. The number of mammals found was 15 species, with six of them being protected species, 1 threatened species and 3 vulnerable species according to IUCN. Enrichment planting of long-life or local native species is necessary to be conducted in order to increase the diversity of flora and fauna. An increase in the variation of local plants species will correlate with the arrival of herbivorous fauna species and phytophagous insects. The arrival of the first-level consumer fauna will spur the presence of the next-level consumer fauna that are both carnivorous and omnivorous. The greater types of fauna that come can bring plant seeds from other sources and grow naturally in the reclamation area. This case study showed mine reclamation can result naturally growth of vegetation and became proper habitat for fauna to return.
\end{abstract}

Keywords: mine reclamation, flora and fauna, conservation status, diversity

\section{$1 \quad$ Introduction}

In addition to contributing positively to national income, mining activities also produce negative impacts on the environment (Environmental Law Alliance Worldwide 2010). The impacts of mining activities include the decline or even loss of biodiversity (Lloyd et al. 2002; Slingenberg et al. 2009), modification of soil conditions (Subowo 2011) and results deep and wide holes (Doupe and Lymbery 2005). To reduce and overcome these impacts, every mining permit must carry out mine reclamation. Mine reclamation is defined by the Decree 
of the Minister of Energy and Mineral Resources of the Republic of Indonesia No. 1827.K / 30 / MEM / 2018 as an activity to restore and improve the quality of the environment and ecosystem of the ex-mining area in accordance with land use during mining operations phase.

Based on the land status (forest and non-forest area), the mining permit holder has the obligation to return the ex-mining land to forest if the mining area is in a forestry area. Conversely, if the mining area is in a nonforestry area, the mining reclamation program can be adjusted to the local spatial plan map, for example: to become a residential area, tourism object, plantation, etc. In addition, the mine permit holder must place a mine reclamation bond that will be released based on the results of an evaluation conducted by the government till meet the success criteria.

Generally, the form of mine reclamation program is revegetation. The program commences with the land recontouring of ex-mined sites and the soil spreading. To prevent the erosion and sedimentation, the facility is built such as drainage, rip rap, drop structure, etc as well as planting the soil cover crop. Besides preventing the erosion, the cover crop is also a source of soil organic matter. Moreover, fast-growing and long-lived local trees species are planted as the revegetation program to enrich the biodiversity (Amanah \& Yunanto 2019).

As a follow up of the reclamation activities, monitoring of terrestrial flora and fauna is very important to know the development of its diversity. The monitoring is one method to measure the success of reclaimed land as a new habitat in the ecosystem. The existence of native wild fauna in the former mining area can be applied as an appropriate indicator. The objectives of this study are: 1) to identify and measure the biodiversity of terrestrial flora, 2) to identify and measure the biodiversity of avifauna and mammal species, 3 ) to determine the conservation status of flora and fauna in the reclamation area, and 4) to compare the biodiversity of flora and fauna in the reclamation area and secondary natural forest.

\section{$2 \quad$ Methodology}

\subsection{Research area}

The study was conducted in the reclamation area of PT Dharma Puspita Mining, Kutai Kartanegara Regency, East Kalimantan from 22 to 28 April 2017, as well as secondary natural forest as comparison. The study was conducted in the reclamation area which was planted in 2006 (11-year-old-plantation), 2007 (10-year-oldplantation) and 2008 (9-year-old-plantation). The area of the mine reclamation were 112.86 ha (Reclamation in 2006), 36.98 ha (Reclamation in 2007), and 6.4 ha (Reclamation in 2008). Mining activity was located in the forest area which the nearest distance between the secondary natural forest and ex-mined reclamation sampling point was $2.37 \mathrm{~km}$. The selected sampling points in the mine reclamation areas were based on the random sampling, whilst the sampling point in the secondary natural forest was based on the nearest location to the site. The study was conducted on three parameters, namely vegetation, avifauna and mammals.

\subsection{Field data collection}

\subsubsection{Vegetation}

Vegetation analysis was conducted using line plot sampling (Figure 1). The line plot sampling was divided into three compartments, namely compartment "a" with a wide of $2 \mathrm{~m}$ (calculating the seedling stage with the characteristics of a total height $(h)$ of $\leq 1.50 \mathrm{~m}$ and as well as implemented for understory), compartment " $b$ " with a wide of $5 \mathrm{~m}$ (measuring trees (sapling stage) that had a diameter at breast height (DBH, $1.3 \mathrm{~m}$ height) $\mathrm{DBH}<10 \mathrm{~cm}$, and compartment " $\mathrm{c}$ " with a wide of $20 \mathrm{~m}$ (measuring trees with a DBH $(1.3 \mathrm{~m}$ height $\geq 10 \mathrm{~cm})$.

\subsubsection{Avifauna}

Avifauna monitoring and identification was carried out in the morning and afternoon using the binocular, mist net, camera as documentation tools and several site guideline books as identification tools. Monitoring was conducted in several points such as in the edge of the forest, which is a proper place for bird watching, under the forest stands particularly in the vicinity of wild animal feeding areas or in traces of animal found 
either in the form of footprints, dirt or others. In addition to observations is the installation of mist nets to catch birds. The net is left in place for 2-3 days both at day and night at several points.

\subsubsection{Mammal}

Site data collection was performed by visual, identification of mammal traces, interview and using camera trap (Wilson et al. 1996). Observation of the presence of mammals by direct observation can be combined with observations of traces left behind, both footprints and other remains such as feathers, claw marks, odours, traces of food and faeces (Rudran et al. 1996). As additional data and comparison, monitoring was also conducted in the secondary forest which is bordered by mine reclamation area.

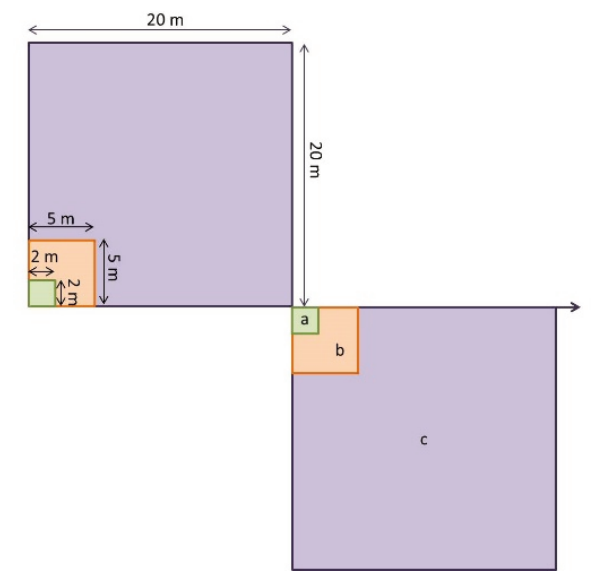

\section{Figure $1 \quad$ Line plot sampling}

\section{Data}

Several parameters were analysed and measured during vegetation analysis included taxon, height and diameter. Furthermore, richness index/Margalef index (R; (Indriyanto 2012)), evenness index/Shannon evenness index (E; (Magurran 1988)) and Shannon-Wiener diversity index ( $H^{\prime}$; (Magurran 1988)). Bird identification was carried out by matching photograph and bird specimen on the identification books. Mammal identification was conducted by analysing the presence of mammal in the study area and Genus and Family Index ( $D_{G-F}$ ( Li et al. 2006 dalam Wenguang et al. 2008)). All the index and formulas are shown in Table 1.

Table $1 \quad$ Algorithms and properties of diversity indices

\begin{tabular}{lll}
\hline Index & Algorithm & Source \\
\hline Margalef index (R) & $R=\frac{\mathrm{s}-1}{\ln n}$ & Magurran 1988 \\
Shannon Wiener Index (H') & $H^{\prime}=-\sum$ pi ln pi & Magurran 1988 \\
Shannon evenness index (E) & $E=\frac{H^{\prime}}{\ln S}$ & Magurran 1988 \\
Genus Family index (DG-F) & $D_{G-F}=1-\frac{D_{G}}{D_{F}}$ & Jiang \& Ji, 1999; Li et al. 2006 in \\
& where: & Wenguang et al. 2008 \\
& $D_{G}=-\sum_{j=1}^{p} q_{j} \ln q_{j}$ & \\
& $D_{F}=\sum_{k=1}^{m} D_{F k}$ & \\
& $D_{F k}=-\sum_{i=1}^{n} p_{i} \ln p_{i}$ & \\
\hline
\end{tabular}


Community criteria based on their richness index, species diversity index and evenness index can be seen in Table 2.

\section{Table 2 Richness index category}

\begin{tabular}{llll}
\hline Index & Category & Index value & Source \\
\hline Richness index & High species richness & $>4$ & Jørgensen et al. 2005 \\
& Medium species richness & $2.5-4$ & \\
& Low species richness & $<2.5$ & Barbour et al. 1987 \\
Diversity index & High diversity & $>3$ & \\
& Medium diversity & $2-3$ & Hill 1973; Magguran 1988 \\
& Low diversity & $0-2$ & \\
Evenness index & Unbalanced & $0.00-0.25$ & \\
& Less balanced & $0.26-0.50$ & \\
& Semi-balanced & $0.51-0.75$ & \\
& Almost balanced & $0.76-0.95$ & \\
& Balanced & $0.96-1.00$ & \\
\hline
\end{tabular}

\section{$4 \quad$ Result and discussion}

\subsection{Vegetation}

Data analysis showed Margalef richness index (R) of nearest secondary forest was high for all stages (Table 3); $R$ of reclamation area in 2006- 2008 was high for seedlings and saplings but low for trees (Figure 2, Figure 3 and Figure 4).

Table 3 Richness index $(\mathrm{R})$, diversity index $\left(\mathrm{H}^{\prime}\right)$ and evenness index $(\mathrm{E})$ of vegetation in the secondary forest and mine reclamation areas

\begin{tabular}{|c|c|c|c|c|c|c|c|c|c|}
\hline Index & $\mathbf{R}$ & & & $\mathbf{H}^{\prime}$ & & & E & & \\
\hline Stand type & seedling & sapling & tree & seedling & sapling & tree & Seedling & sapling & tree \\
\hline Secondary forest & 6.06 & 4.49 & 6.78 & 2.88 & 2.56 & 2.96 & 0.82 & 0.86 & 0.84 \\
\hline $\begin{array}{l}\text { Reclamation in } \\
2006\end{array}$ & 8.30 & 6.82 & 2.02 & 2.94 & 3.04 & 1.02 & 0.75 & 0.85 & 0.41 \\
\hline $\begin{array}{l}\text { Reclamation in } \\
2007\end{array}$ & 6.66 & 6.73 & 2.45 & 2.84 & 2.80 & 1.23 & 0.76 & 0.78 & 0.47 \\
\hline $\begin{array}{l}\text { Reclamation in } \\
2008\end{array}$ & 6.52 & 6.13 & 1.55 & 2.67 & 3.04 & 0.36 & 0.71 & 0.93 & 0.16 \\
\hline
\end{tabular}

The diversity index $\left(\mathrm{H}^{\prime}\right)$ in secondary forest was moderate for all stages and $\mathrm{H}^{\prime}$ of reclamation area in 2007 was moderate for seedlings and saplings and low for trees (Figure 3). Both reclamation in 2006 and reclamation in 2008 had same values of $\mathrm{H}^{\prime}$ where they were high for saplings, moderate for seedlings and low for trees (Figure 2 and Figure 4). 

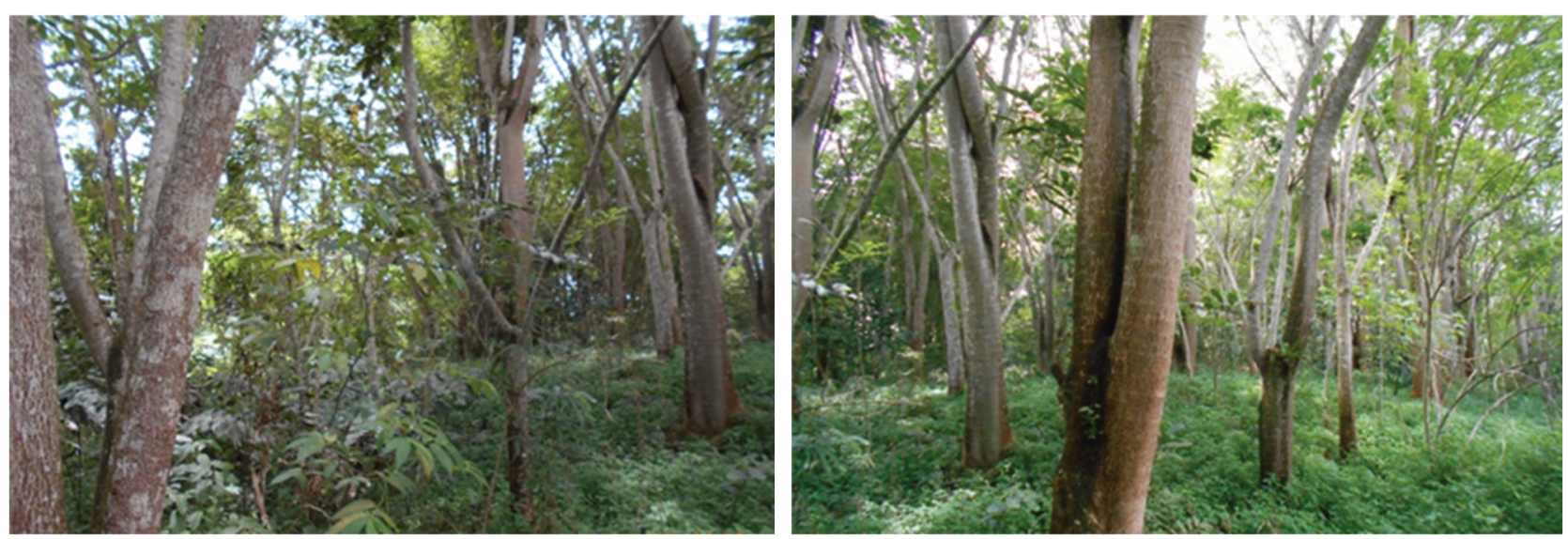

\section{Figure 2 Vegetation in reclamation 2006}
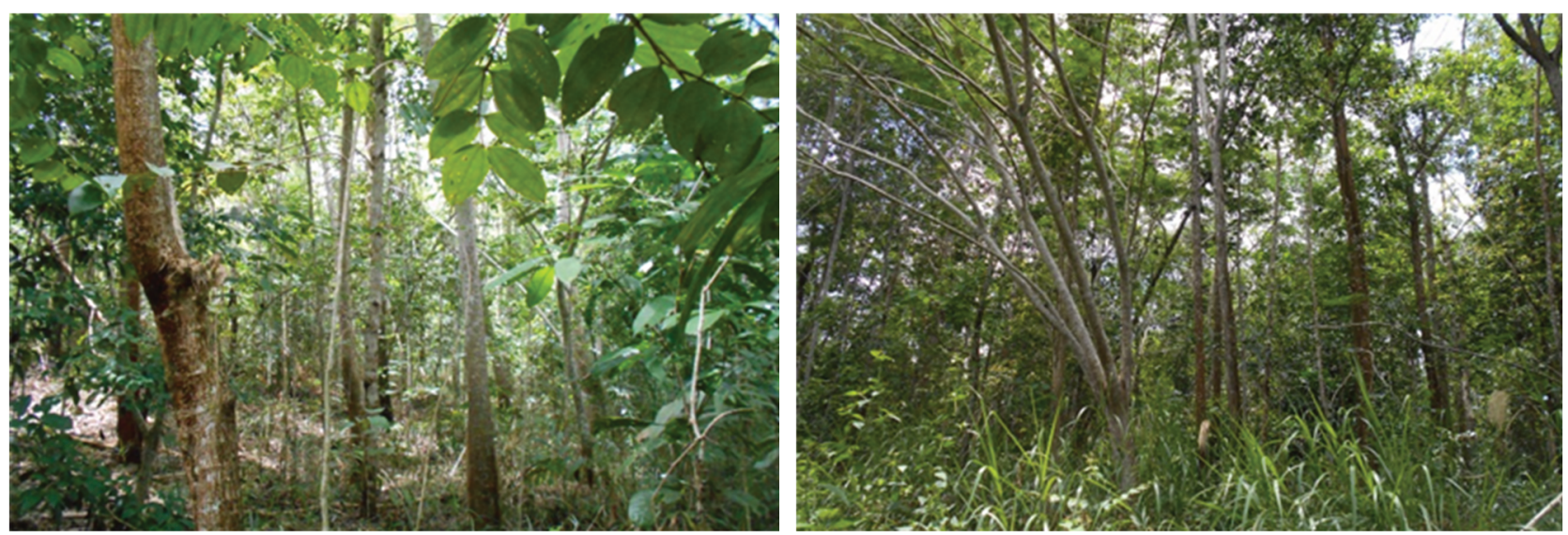

\section{Figure 3 Vegetation in reclamation 2007}
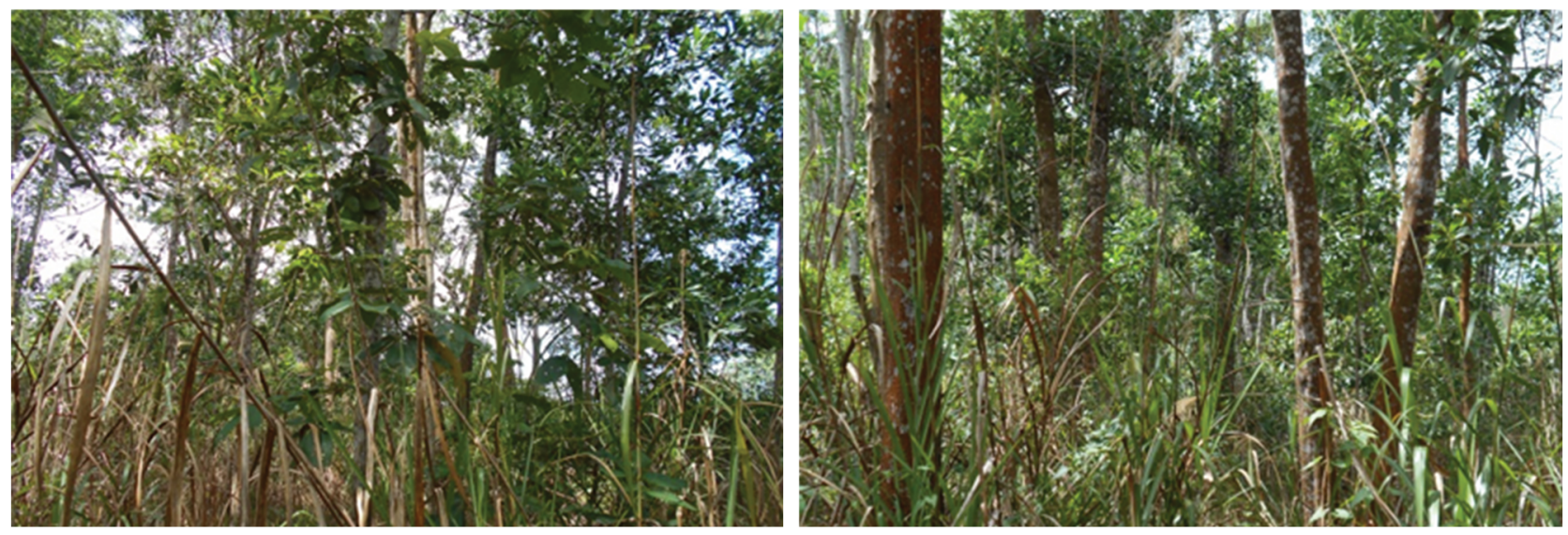

\section{Figure 4 Vegetation in reclamation 2008}

The evenness index (E) which is higher or close to 1 defines the number of individual vegetation evenly distributed in each species. Conversely, if it is lower or close to 0 , it means the distribution of the number of individual species is uneven. The results showed that the evenness index $(E)$ in secondary forest was almost equal for all stages; in the reclamation area in 2006, sapling was classified as almost evenly, seedling was classified as fair and tree was classified as less evenly; in the reclamation area in 2007, seedling and sapling 
were classified as almost evenly and tree was classified as less evenly; in the reclamation area in 2008, sapling was classified as almost evenly, seedling was classified as fair and tree was classified as uneven.

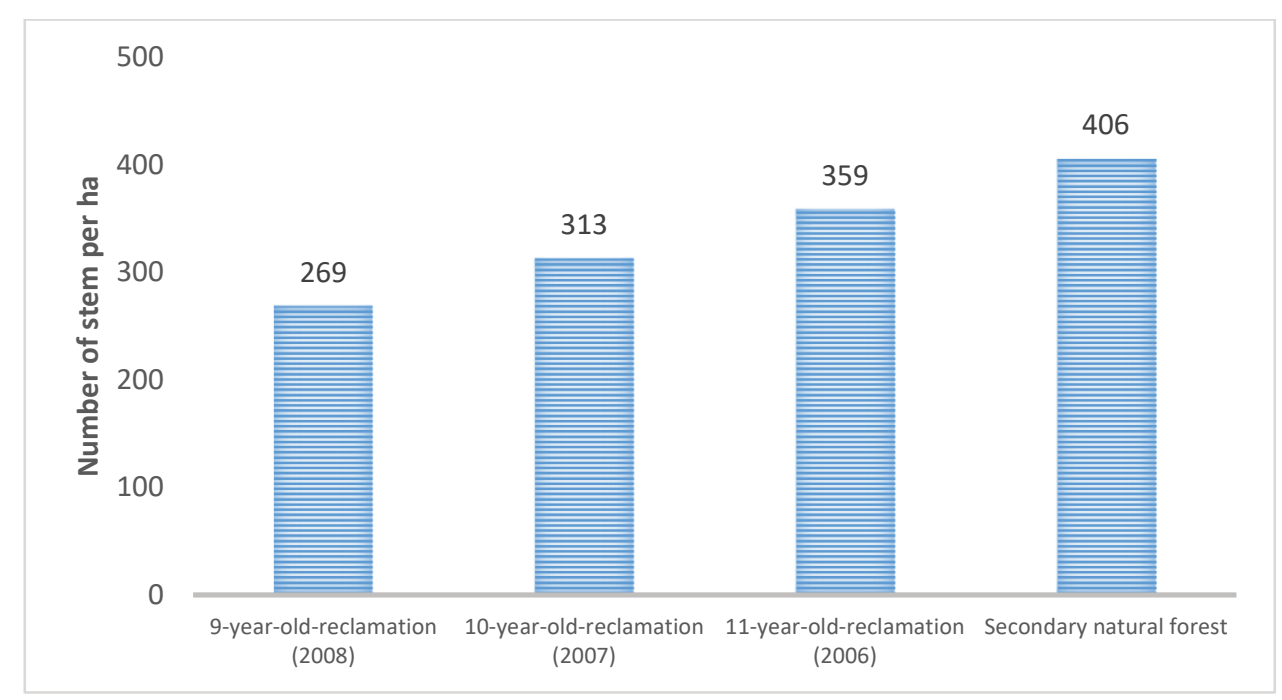

\section{Figure $5 \quad$ Number of stems per ha}

The density of trees per hectare showed that the older plant, the closer or almost the same as the density per hectare of trees in the nearest secondary forest (Figure 5). Considering the diversity index, the same pattern also occurred because $\mathrm{H}^{\prime}$ value of reclamation in 2008 was relatively low. However, $\mathrm{H}^{\prime}$ started to increase for reclamation in 2007 and 2006 that classified as moderate. As reclamation ages increase, exmining areas can be ecologically restored to self-sustainable forests (Prach et al. 2001; Holl 2002; Frouz et al. 2008). It also showed that succession also worked and was marked by the change of tree species. The planted pioneer species began to die because they have reached their age and were replaced by other species that grew naturally (Figure 6). The planting of pioneering species aims to create an appropriate microclimate so that natural regeneration occurs in the reclamation area (Grant and Koch 2007).
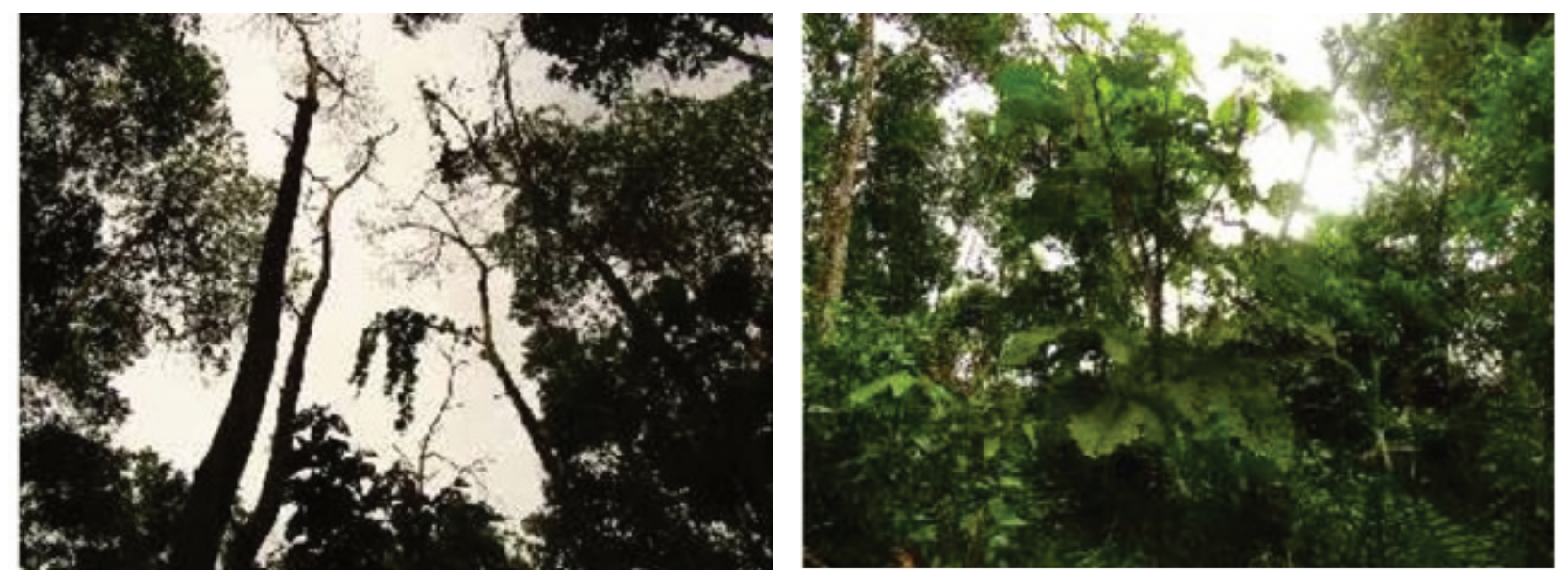

Figure 6 Planted pioneer species died because of the age and were changed by other naturally grown species Source: Anonim, 2017

The data showed that from 14 protected plant species (Table 4) in the reclamation area and secondary forest, there were eight species which were enlisted in the red list of threatened species based on International Union for Conservation of Nature (IUCN) where Shorea gratissima Dyer was enlisted as endangered species (EN). The others 7 species are included in the IUCN least Concern (LC) category. 
Table 4 Species with conservation status in the secondary forest and mine reclamation areas

\begin{tabular}{|c|c|c|c|c|c|c|}
\hline No & Family & Species name & IUCN & CITES & END & Origin \\
\hline 1 & Anacardiaceae & Melanochyla bullata Ding Hou & & & $*$ & SF \\
\hline 2 & Dilleniaceae & Dillenia borneensis Hoogland & & & $*$ & SF \\
\hline 3 & Dipterocarpaceae & Shorea gratissima Dyer & EN & & & Rec \\
\hline 4 & Ebenaceae & Diospyros borneensis Hiern & & II & & SF \\
\hline 5 & Euphorbiaceae & Macaranga pearsonii Merr. & & & $*$ & $\operatorname{Rec}$ \\
\hline 6 & Leguminosae & Bauhinia purpurea $\mathrm{L}$. & LC & & & $\operatorname{Rec}$ \\
\hline 7 & Lygodiaceae & Lygodium microphyllum (Cav.) R. Br. & LC & & & $\operatorname{Rec}$ \\
\hline 8 & Moraceae & Ficus uncinata (King) Becc. & & & $*$ & $\operatorname{Rec}$ \\
\hline 9 & Myristicaceae & Horsfieldia wallichii Warb. & LC & & & $\operatorname{Rec}$ \\
\hline 10 & Myristicaceae & Myristica iners Blume & LC & & & SF \\
\hline 11 & Poaceae & Paspalum conjugatum P.J. Bergius & LC & & & $\operatorname{Rec}$ \\
\hline 12 & Poaceae & Paspalum scrobiculatum L. & LC & & & $\operatorname{Rec}$ \\
\hline 13 & Poaceae & Saccharum spontaneum L. & LC & & & $\operatorname{Rec}$ \\
\hline 14 & Symplocaceae & Symplocos costatifructa Noot. & & & $*$ & Rec \\
\hline
\end{tabular}

Note:

II = Appendix II (list of species that unthreatened with extinction but enable to be extinct due to continuous trade without regulation)

$\mathrm{EN} \quad=$ Endangered

$\mathrm{LC}=$ Least concern (low risk)

END = Endemic (for Kalimantan Island only)

SF $\quad=$ Secondary forest

Rec = Reclamation

There were five endemic species which were only lived in Kalimantan such as Melanochyla bullata Ding Hou (Anacardiaceae), Dillenia borneensis Hoogland (Dilleniaceae), Macaranga pearsonii Merr. (Euphorbiaceae), Ficus uncinata (King) Becc. (Moraceae) dan Symplocos costatifructa Noot. (Symplocaceae). In addition, based on the Table 4, the species of Diospyros borneensis Hiern (Ebenaceae) belonged to Appendix II CITES.

\subsection{Avifauna}

A total of 59 bird species were found in the study area. Most of them were identified as insectivores, which were a combination of species that live in open areas and natural forests (undergrowth). Kacer (Copsychus saularis) and Magpie stone (Copsychus malabarichus) were two commercial bird species that were heard around the study area but were not caught in the net. This condition may be caused by the plantation of several species of the Dipterocarpaceae family in the reclamation area, so that some species of birds have returned. In addition, another factor that strengthens the stability of bird ecosystems in the reclamation area was the presence of remaining secondary forest in the western part of the mine reclamation area. 


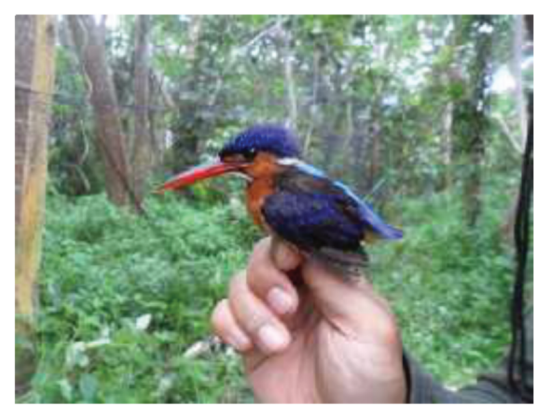

(a)

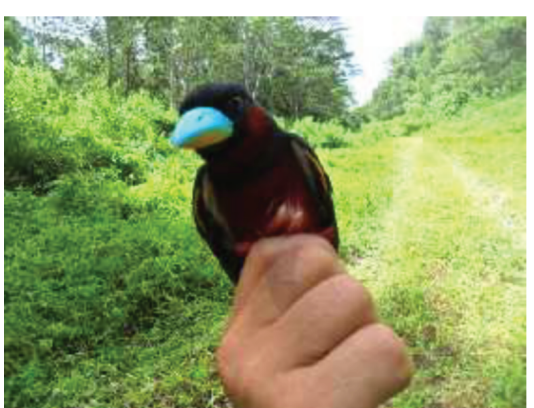

(b)

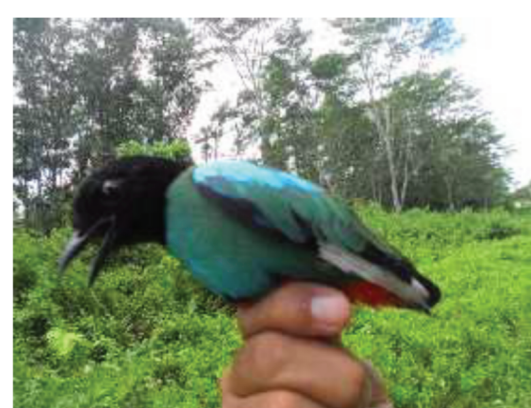

(c)

Figure 7 Bird species found in mine reclamation area: (a) Alcedo meninting, (b) Cymbirhynchus macrorhynchos, (c) Pitta sordida Source: PT Dharma Puspita Mining, 2017

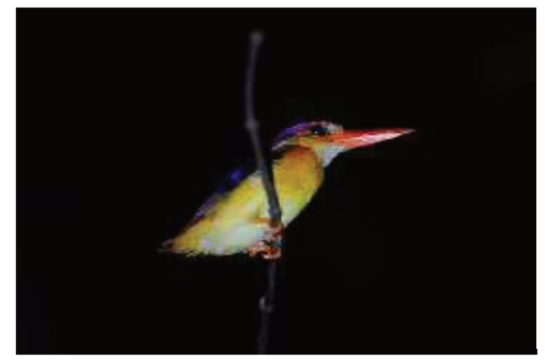

(a)

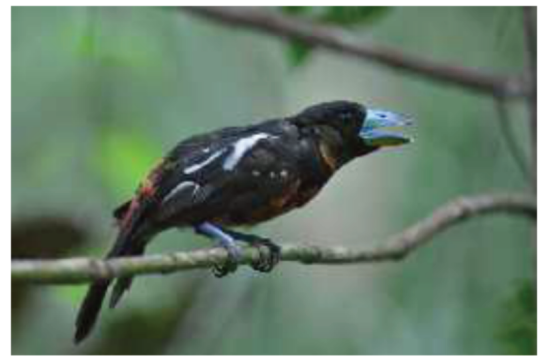

(b)

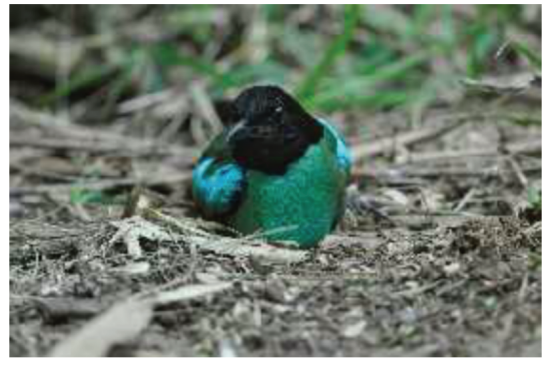

(c)

Figure 8 Birds species found in the secondary forest: (a) Alcedo meninting, (b) Cymbirhynchus macrorhynchos, (c) Pitta sordida Source: PT Dharma Puspita Mining, 2017

Some species of birds found were categorized as rare and protected such as all species of honey-sucking birds (Family Nectarinidae), King Shrimp (Family Alcedinidae) and birds of prey (Family Accipitridae). In addition, endemic species was also found, such as Dusky munia (Lonchura fuscans), a type of bondol bird that lived in groups. However, this species was not categorized as rare because it was found in almost reclamation areas in Kalimantan. The Lonchura malacca species was also a bondol bird that was often found and had a wide distribution in Kalimantan. However, Alcedo meninting, Cymbirhinchus macrorhynchos and Pitta sordida, which were listed in the rare category, were found in both mine reclamation areas and secondary natural forest (Figure 7 and Figure 8).

Classification based on diet/food class is a method for classifying of tropical birds. In general, the food/diet class was created based on the type of food, how and where the food is obtained, and the behaviour of the bird in getting food. For instance, birds that forage between leaves in the canopy are categorized as Arboreal Foliage Gleaning Insectivore (AFGI). Aerial Insectivores (AI) are hunting species prey birds in the form of insects in the air or Terrestrial Frugivore (TF) are frugivorous birds that live on the forest floor. The presence of bird species can be a guideline specially to indicate the presence of their feed (either vegetation or insects or micro-fauna such as earthworms) and plants species diversity. Homogeneous habitat tends to have individual dominance of several plant species, while natural forest has a high species composition without any dominance in the individual distribution.

Some bird species are very specific to show area condition such as AFGI which are uncommon in open space area. Conversely, some bird species in open space area is a guide for forest cover alteration. Some interpretations can be made by looking at the bird presence and composition. However, it is necessary to understand the power of flight and diet/food specification as a reference of area classification. Therefore, larger map analysis is essential to describe the relationship between the study area and its vicinity. Comprehensive relationship between presence and absence of some species and power flight in finding food is also important to avoid misunderstanding of species number. This study showed that some species based on diet/food category were found in the mine reclamation area (Figure 9). It also means that mine reclamation area provided variety of bird food both insects and fruits. 
However, mine reclamation creates natural succession on the ex-mining land. Birds come to the early step of succession where the pioneer trees are planted as habitat (Groninger et al. 2007; Bell et al. 2017). Birds have important role to bring the seeds from the secondary natural forest. The seeds result natural regeneration on mine reclamation land. In accordance with the bird diversity, vegetation diversity on mine reclamation area is the key because monoculture leads to low diversity bird species (Borthwick \& Wang 2015).

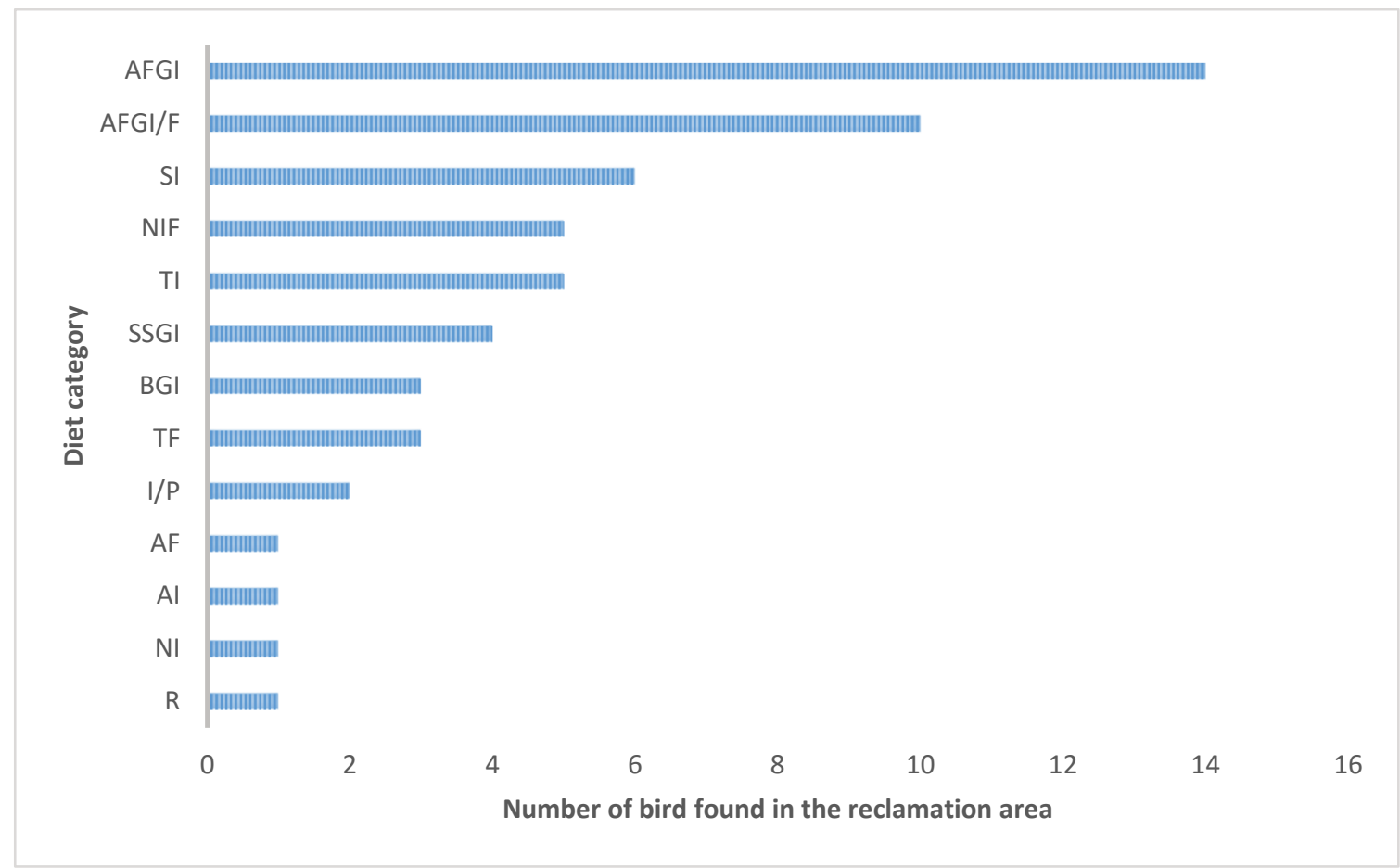

\section{Figure 9 Identified bird species based on diet/food category in the mine reclamation area}

Note:

AFGI = Arboreal Foliage Gleaning Insectivore

$\mathrm{AFGI} / \mathrm{F}=$ Arboreal Foliage Gleaning Insectivore/Frugivore

SI = Sallying Insectivore

NIF $=$ Nectarivore/Insectivore/Frugivore

$\mathrm{TI}=$ Terrestrial Insectivore

SSGI = Sallying Substrate Gleaning Insectivore

BGI = Bark Gleaning Insectivore

TF = Terrestrial Frugivore

$\mathrm{I} / \mathrm{P}=$ Insectivore/Piscivore

$\mathrm{AF} \quad=$ Arboreal Frugivore

Al = Arboreal Insectivore

$\mathrm{NI}=$ Nectarivore Insectivore

$\mathrm{R}=$ Raptor 


\subsection{Mammal}

A total of 15 mammals were found in both the reclamation area and secondary forest by direct monitoring, footprint identification, camera traps and local interviews (Table 5). Three of them were documented by camera traps. In general, there were no signs of mammals using reclaimed areas for breeding and nesting, except for small mammals (rats). However, the presence of these mammals is an indicator that ecologically the reclamation area has developed into a natural habitat for mammals. The presence of these mammals can be an agent for spreading seeds in reclaimed land. Meanwhile, the existence of the nearest secondary forest can be a source of presence of mammals around the reclamation area.

Table 5 Identified mammal species in the mine reclamation areas and nearest secondary forest

\begin{tabular}{|c|c|c|c|c|}
\hline No & Species name & Local name & Monitoring method & Note \\
\hline 1 & Cynopterus brachyotis & codor krawar & mist net & Reclamation \\
\hline 2 & Hypposideros sp. & barong & mist net & Reclamation \\
\hline 3 & Rhinolophus trifoliatus & $\begin{array}{l}\text { kelekawar ladam } \\
\text { lappet kuning }\end{array}$ & mist net & Reclamation \\
\hline 4 & Collosciurus notatus & bajing kelapa & direct & Reclamation \\
\hline 5 & Tupaidae sp. & tupai & camera trap & Reclamation \\
\hline 6 & Ratus spp. & tikus & direct, camera trap & $\begin{array}{l}\text { Reclamation \& } \\
\text { Secondary forest }\end{array}$ \\
\hline 7 & Macaca fascicularis & kera & direct, camera trap & $\begin{array}{l}\text { Reclamation \& } \\
\text { Secondary forest }\end{array}$ \\
\hline 8 & Hylobates muelleri & owa & voice & Secondary forest \\
\hline 9 & Helarctos malayanus & beruang madu & scratch & $\begin{array}{l}\text { Reclamation \& } \\
\text { Secondary forest }\end{array}$ \\
\hline 10 & Paradoxurus hermaproditus & musang luwak & direct & $\begin{array}{l}\text { Reclamation \& } \\
\text { Secondary forest }\end{array}$ \\
\hline 11 & Prionailurus bengalensis & kucing kuwuk & direct, footprint & $\begin{array}{l}\text { Reclamation \& } \\
\text { Secondary forest }\end{array}$ \\
\hline 12 & Rusa unicolor & rusa & footprint, interview & $\begin{array}{l}\text { Reclamation \& } \\
\text { Secondary forest }\end{array}$ \\
\hline 13 & Muntiacus atherodes & kijang & footprint, interview & $\begin{array}{l}\text { Reclamation \& } \\
\text { Secondary forest }\end{array}$ \\
\hline 14 & Tragulus napu & pelanduk napu & footprint, interview & $\begin{array}{l}\text { Reclamation \& } \\
\text { Secondary forest }\end{array}$ \\
\hline 15 & Sus barbatus & babi & footprint & $\begin{array}{l}\text { Reclamation \& } \\
\text { Secondary forest }\end{array}$ \\
\hline
\end{tabular}

The data showed that the GF index of mammal species were 2.71 for family index, 2.21 for genus index and 0.81 for GF index. The result showed that the diversity of mammals both in the reclamation area and surrounding PT Dharma Puspita Mining were low. As comparison, GF index of mammal in East Kalimantan was 11.77 for family index, 2.83 for genus index and 0.67 for GF index. Furthermore, GF index of mammal in Kalimantan was 13.36 for family index, 3.96 for genus index and 0.70 for GF index. Considering GF index in East Kalimantan and Kalimantan, it showed that mammal diversity in the study area was $10 \%$ of East Kalimantan's and 6\% of Kalimantan's, excluding Chiroptera order (bat). The data also showed that in the 
reclamation area there were 4 orders of 10 in Kalimantan and East Kalimantan. Comparing to monitoring period, diet/food category and mammal distribution based on GF index, the mammal diversity in the reclamation area was low. For further study, the area monitoring of mammals can be extended to collect more data.

The Shannon-Wiener Index showed the diversity of mammals in the reclamation area and its surroundings was 1.20. This means that the diversity of mammals in this area is sufficient. The use of this index is very biased due to the diversity of taxon that is not diverse. In addition, the mine reclamation area is not yet a suitable habitat. The presence of mammals in the reclamation area is not absolute but only a temporary place to look for their food. Index comparisons are more appropriate when applied between the study area and the nearest secondary forest. At least $67 \%$ of species identified in secondary forests also exist in reclamation areas. The condition of vegetation cover and the distance between secondary forest and reclamation areas are the main factors of the presence of mammals in the mine reclamation area.

There are 15 protected mammals found in the reclamation area (Table 6). Some mammals are included in Appendix I in CITES such as Hylobates muelleri, Helarctos malayanus and Prionailurus bengalensis, while Macaca fascicularis is included in CITES Appendix II. According to the IUCN list, Hylobates muelleri is also an endangered species. In general, protected mammals found in reclamation areas were included in the IUCN in the Least Concern (LC) category.

Table 6 Identified mammal species with conservation and protection status in the mine reclamation areas and nearest secondary forest

\begin{tabular}{lllll}
\hline No & Species name & Local name & \multicolumn{2}{l}{ Conservation status } \\
& & & IUCN & CITES \\
\hline 1 & Cynopterus brachyotis & codor krawar & LC & \\
2 & Hypposideros sp. & barong & LC & \\
3 & Rhinolophus trifoliatus & kelekawar ladam & LC & \\
& & lappet kuning & & \\
4 & Collosciurus notatus & bajing kelapa & LC & \\
5 & Tupaidae sp. & tupai & LC & App II \\
6 & Ratus spp. & tikus & LC & App I \\
7 & Macaca fascicularis & kera & LC & App I \\
8 & Hylobates muelleri & owa & EN & \\
9 & Helarctos malayanus & beruang madu & VU \\
10 & Paradoxurus hermaproditus & musang luwak & LC & App I \\
11 & Prionailurus bengalensis & kucing kuwuk & LC & \\
12 & Rusa unicolor & rusa & VU & \\
13 & Muntiacus atherodes & kijang & LC & \\
14 & Tragulus napu & pelanduk napu & LC & VU \\
15 & Sus barbatus & babi & L & \\
\hline
\end{tabular}

Mammals with high mobility are also potential to spread the seeds through the diets as dispersal agent (Soendjoto et al. 2014; Komara et al. 2016). However, in the early succession, pioneer plants attract small mammals to come as habitat (Bell et al. 2017). In addition, mammals are also attracted by diets source and 
crossing area (Kirmi et al. 2019). Furthermore, the presence of mammals in mine reclamation area shows ecosystem stability.

The reclamation and revegetation program carried out by PT Dharma Puspita Mining has triggered the arrival of other flora and fauna into the reclamation area. Planting pioneer trees followed by planting long-lived plants (preferably local species) is a stimulant in the formation of new habitats. Vegetation that grows naturally due to the formation of a microclimate will directly enrich the ecosystem in addition to pioneer plants. The arrival of herbivorous fauna and fitofag insects has a correlation with plant diversity. The arrival of the first consumer will spur the next carnivorous and omnivorous consumer level fauna. This series is an overview of the restoration process in the reclamation area of PT Dharma Puspita Mining.

Based on vegetation data, there has been a significant development of the revegetation period where the age of revegetation correlates with increased diversity, equality and stability. Monitoring data showed that vegetation in the reclamation area was continuing towards ecosystem stability. The tree stage from all reclamation areas had low diversity and stability, while the seedling and sapling stages showed promising potential. This offers hope over time, through changing vegetation types from pioneers to long-lived species will create community stability that resembles natural habitat.

In general, the results of studies in animals in the reclamation area showed that the succession process was on-going and has passed an initial phase with the formation of a pioneering community. To form a stable forest ecosystem, natural regeneration or some accelerated processes through constructive enrichment and management are needed.

\section{Conclusion}

The ecological perspective shows that the evaluated reclamation area has exceeded the initial succession stage. Invasion and aggregation with the formation and vegetation of shrub communities in 2006 are in transition to young secondary forest communities. In order to ensure ecosystem stability, it is necessary to accelerate the stability of forest ecosystems such as conducting the enrichment activities. Field observation shows that direct and indirect threats to the existence of flora and fauna diversity in the reclamation area are hunting, encroachment, land clearing, and fire.

\section{Acknowledgment}

This study was funded by PT Dharma Puspita Mining, part of Harita Group. We also thank to Directorate General for Mineral and Coal, Ministry of Energy and Mineral Resources, Faculty of Forestry, Mulawarman University and all parties who have assisted us in this study.

\section{Reference}

Amanah, F \& Yunanto, T 2019, 'Mine reclamation period to successfully meet in Indonesia', in AB Fourie \& M Tibbett (eds), Proceedings of the 13th International Conference on Mine Closure, Australian Centre for Geomechanics, Perth, pp. 13031314.

Barbour, GM, Burk, JK \& Pitts, WD 1987, Terrestrial Plant Ecology, The Benyamin/Cummings, Menlo Park, CA.

Bell, G, Sena, KL, Barton, CD \& French, M 2017, 'Establishing pine monocultures and mixed pine-hardwood stands on reclaimed surface mined land in Eastern Kentucky: Implications for forest resilience in a changing climate', Forest, vol. 8, pp. 1-11.

Borthwick, RR \& Wang, Y 2015, 'Bird species' responses to post mine reclamation in ALABAMA - A preliminary analysis', Journal of The American Society of Mining and Reclamation, vol. 4, no. 2, pp. 1-19.

Doupé, RG \& Lymbery, AJ 2005, 'Environmental risks associated with beneficial end uses of mine lakes in Southwestern Australia', Mine Water and the Environment, vol. 24, pp. 134-138.

Environmental Law Alliance Worldwide 2010, Guidebook for Evaluating Mining Projects EIAs, 1st edition, Environmental Law Alliance Worldwide, Eugene, Oregon.

Frouz, J, Prach, K, Pižl, V, Háněl, L, Starý, J, Tajovský, K, Řehounková, K 2008, 'Interactions between soil development, vegetation and soil fauna during spontaneous succession in post mining sites', European Journal of Soil Biology, vol. 44, pp. 109-121.

Grant, C \& Koch, J 2007, 'Decommissioning Western Australia's first bauxite mine: co-evolving vegetation restoration techniques and targets', Ecological Management \& Restoration, vol. 8, no. 2, pp. 92-105. 
Groninger, J, Skousen, J, Angel, P, Barton C, Burger, J \& Zipper, C 2007, 'Mine reclamation practoces to enhance forest development through natural succession', Forest Reclamation Advisory, no. 5, pp. 1-5.

Hill, MO 1973, 'Diversity and evenness: A unifying notation and its consequences', Ecology, vol. 54, no. 2, pp. 427-432

Holl, KD 2002, 'Long-term vegetation recovery on reclaimed coal surface mines in the eastern USA', Journal of Applied Ecology, vol 39, pp. 960-970.

Indriyanto 2012, Ekologi Hutan, Bumi Aksara, Jakarta.

Jørgensen, SE, Costanza, R, \& Xu, FL 2005, Handbook of ecological indicators for assesment of ecosystem health, C.R.C Press, Boca Raton.

Kirmi, H, Anwar, S, Masyhuri, M \& Prasetiyo, DE 2019, Tingkat Kehadiran dan Keanekaragaman Jenis Mammalia di Areal Reklamasi PT Berau Coal, Kalimantan Timur', Jurnal Biologi dan Pendidikan Biologi, vol. 5, no. 1, pp. 35-45.

Komara, L, Choesin, DN \& Syamsudin, TS 2016, 'Plant diversity after sixteen years post coal mining in East Kalimantan, Indonesia', Biodiversitas, vol. 17, no. 2, pp. 531-538.

Lloyd, MV, Doherty, MD, Jeffree, RA, John, J, Majer, JD, Osborne, JM \& Nichols, OG 2002, Managing the Impacts of the Australian Minerals Industry on Biodiversity, Australian Centre for Mining Environmental, London.

Magurran, AA 1988, Ecological Diversity and Its Measurement, Springer, Dordrecht.

Prach, K, Bartha, S, Joyce, CB, Diggelen, R, \& Wiegleb, G 2009, 'The role of spontaneous vegetation succession in ecosystem restoration: A perspective', Applied Vegetation Science, vol. 4, pp. 111-114.

PT Dharma Puspita Mining, 2017, Studi identifikasi flora dan fauna di areal reklamasi pascatambang PT Dharma Puspita Mining, Kabupaten Kutai Kartanegara, PT Dharma Puspita Mining-Universitas Mulawarman, Samarinda.

Rudran, R, Kunz, TH, Southwell, C, Jarman, P \& Smith, AP 1996, 'Observational techniques for non-volant mammals', in DE Wilson, FR Cole, JD Nichols, R Rudran, MS Foster (Eds.) Measuring and monitoring biological diversity: Standard method for mammals, Smithsonian Institution Press, Washington, D.C., and London, pp. 81-104.

Slingenberg, A, Braat, L, Windt, H, Rademaekers, K, Eichler, L \& Turner, K 2009, Study on understanding the causes of biodiversity loss and the policy assessment framework. ECORYS Nederland BV, Rotterdam.

Soendjoto, MA, Dharmono, Mahrudin, Riefani, MK \& Triwibowo, D 2014, 'Plant species richness after revegetation on the reclaimed coal mine land of PT Adaro Indonesia, South Kalimantan', Jurnal Manajemen Hutan Tropika, vol. XX, no. 3, pp. 150-158.

Subowo, G 2011, 'Penambangan sistem terbuka ramah lingkungan dan upaya reklamasi pascatambang untuk memperbaiki kualitas sumberdaya lahan dan hayati tanah', Jurnal Sumberdaya Lahan, vol. 5, no. 2, pp. 83-94.

Wenguang, Z, Yuanman, H, Jinchu, H, Yu, C, Jing, Z \& Miao, L 2008, 'Impact of land-use change on mammals of Minjiang River, China: implications for biodiversity conservation planning', J. Lanscape and Urban Planning, vol. 85, pp. 195-204.

Wilson, DE, Cole, FR, Nichols, JD, Rudran, R \& Foster, MS 1996, Measuring and monitoring biological diversity: Standard method for mammals, II series, Smithsonian Institution, Washington D.C. 